\title{
Evaluasi Penggunaan Listrik dengan Metode Konservasi Energi untuk Efisiensi Energi di Gedung FKIP UNTIRTA
}

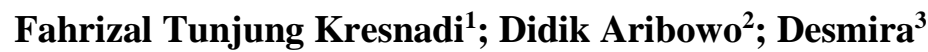 \\ ${ }^{1,2,3}$ Universitas Sultang Ageng Tirtayasa \\ 1'fahrizaltunjung96@gmail.com; ${ }^{2}$ d_aribowo@untirta.ac.id; ${ }^{3}$ desmira@untirta.ac.id
}

\begin{abstract}
Knowing the level of intensity of energy consumption (IKE) in the FKIP Untirta building using the energy audit method for achieving energy efficiency. The data used in data collection in the form of electricity usage data, building area data and observations made by researchers. Analysis of the data used in this study is to use the formula of energy consumption intensity. The results showed the $I K E$ value of the CB FKIP Untirta building was $254.5 \mathrm{kWh} / \mathrm{m}^{2}$. With these results, it can be seen that the IKE value in the CB FKIP Untirta building is still inefficient. This is based on ASEAN-USAID parameters which range at $240 \mathrm{kWh} / \mathrm{m}^{2}$. Based on electrical energy consumption in the CB FKIP Untirta building there is an opportunity for energy saving or energy saving solutions that are replacing TL lamps with Led lights or by replacing TL lamps that are smaller watts and in terms of air conditioning or air conditioning load replacing $R 32$ refrigerant with $R 32$ refrigerant mixture and The R290 has proven to be quite efficient in terms of savings and energy efficiency. And the duration of use of electrical energy.
\end{abstract}

Keywords: Energy audit, energy consumption intensity, energy savings

\begin{abstract}
ABSTRAK
Mengetahui tingkat intensitas konsumsi energi (IKE) di gedung FKIP Untirta dengan menggunakan metode audit energi demi tercapainya efisiensi energi. Data yang digunakan dalam pengumpulan data berupa data penggunaan listrik, data luas bangunan gedung dan observasi yang dilakukan oleh peneliti. Analisis data yang digunakan pada penelitian ini adalah dengan menggunakan rumus intensitas konsumsi energi. Hasil penelitian menunjukkan Nilai IKE gedung CB FKIP Untirta sebesar 254,5 kWh/m ${ }^{2}$. Dengan diperoleh hasil tersebut, bisa diketahui bahwa nilai IKE di gedung CB FKIP Untirta masih tidak efisien. Ini didasarkan pada parameter ASEAN-USAID yang berkisar di $240 \mathrm{kWh} / \mathrm{m}^{2}$. Berdasarkan konsumsi energi listrik di gedung CB FKIP Untirta didapatkan peluang penghematan energi atau solusi penghematan energi yaitu mengganti lampu TL dengan lampu Led atau dengan mengganti lampu TL yang lebih kecil wattnya dan dari segi beban tata udara atau AC yaitu mengganti refrigeran $R 32$ dengan refrigeran campuran $R 32$ dan $R 290$ yang terbukti cukup hemat dalam hal penghematan dan efisiensi energi. Serta, durasi penggunaan energi listrik.
\end{abstract}

Kata kunci: Audit energi, intensitas konsumsi energi, penghematan energi 


\section{Energi dan Kelistrikan: Jurnal Ilmiah}

Vol. 12, No. 1, Januari - Juni 2020, P-ISSN 1979-0783, E-ISSN 2655-5042

https://doi.org/10.33322/energi.v12i1.949

\section{PENDAHULUAN}

Audit energi yaitu metode untuk menghitung tingkat konsumsi energi suatu bangunan. Kemudian hasil audit energi akan dibandingkan dengan standar yang ada dan kemudian mencari solusi untuk menghemat konsumsi energi jika tingkat konsumsi energi melebihi standar yang ada. Mengingat gedung FKIP Untirta belum pernah dilakukan audit energi maka penggunaan energi di FKIP Untirta belum bisa dikatakan efisien, oleh karena itu perlu dilakukan kegiatan audit energi di FKIP Untirta dengan tujuan untuk mengetahui profil penggunaan energi, dan besarnya intensitas konsumsi energi serta tingkat efisiensi di FKIP Untirta. Bila ini dibiarkan, maka akan mempengaruhi kegiatan kuliah di gedung.

Penelitian ini membahas tentang intensitas konsumsi energi (IKE) yang akan mempengaruhi peluang penghematan energi di gedung CB FKIP Untirta. Faktor nilai IKE terdapat pada jumlah konsumsi energi $(\mathrm{kWh})$ per meter persegi $\left(\mathrm{m}^{2}\right)$ per bulan. Angka IKE $\left(\mathrm{kWh} / \mathrm{m}^{2} / \mathrm{bulan}\right)$ diperoleh dengan perbandingan jumlah penggunaan listrik $\mathrm{kWh}$ selama sebulan dengan luas bangunan yang digunakan. Intensitas konsumsi energi (IKE) listrik adalah suatu istilah yang dipakai agar menentukan jumlah konsumsi energi dalam suatu sistem (bangunan). Audit energi dilakukan dengan persiapan terkait administrasi dan kelengkapan pelaksanaan survei perlu dilakukan. Langkahlangkah untuk mempersiapkan audit energi terkait dengan menetapkan tujuan, jenis audit energi, pengadaan kelengkapan audit energi, menentukan jadwal, menentukan metode pengumpulan data dan metode analisis yang diperlukan, menentukan tim pelaksana audit, mengukur peralatan untuk survei lapangan, dan anggaran yang diperlukan untuk membiayai audit energi sampai selesai.

Tujuan penelitian ini adalah menentukan nilai intensitas konsumsi energi (IKE) di gedung CB FKIP Untirta berdasarkan unsur perbandingan total $\mathrm{kWh}$ dan luas gedung dalam perhitungan rumus IKE dengan metode audit energi.

Manfaat penelitian ini untuk mengetahui besarnya intensitas konsumsi energi terutama energi listrik di gedung CB FKIP Untirta sehingga, didapatkan peluang penghematan energi di gedung CB FKIP Untirta.

\section{METODE/PERANCANGAN PENELITIAN}

\subsection{Data Penelitian}

\subsubsection{Data Profil Gedung}

Berdasarkan data yang diperoleh dengan observasi lapangan. Gedung ini terdiri dari 3 lantai dengan luas $479 \mathrm{~m}^{2}$. Gedung ini berdasarkan jumlah ruangannya yaitu ada Ruang Dekan, Rapat, Dekanat, Tata Usaha, Perpustakaan, kelas dan selebihnya dengan rincian sebagai berikut:

Tabel 1. Luas Ruangan

\begin{tabular}{|c|c|c|}
\hline NO & Nama Ruangan & Luas $\left.\mathbf{( m}^{\mathbf{2}}\right)$ \\
\hline & \multicolumn{2}{|c|}{ Lantai 1 } \\
\hline 1 & Ruang Dekan & 36,98 \\
\hline 2 & Ruang Rapat & 36,98 \\
\hline 3 & Ruang Dekanat & 73,96 \\
\hline 4 & Ruang Tata Usaha & 73,96 \\
\hline 5 & Perpustakaan & 73,96 \\
\hline 6 & Toilet & 21,5 \\
\hline 7 & Lorong & 82,74 \\
\hline \multicolumn{2}{|c|}{ Lantai 2 } \\
\hline 8 & Lab Komputer \\
\hline
\end{tabular}


Energi dan Kelistrikan: Jurnal Ilmiah

Vol. 12, No. 1, Januari - Juni 2020, P-ISSN 1979-0783, E-ISSN 2655-5042 https://doi.org/10.33322/energi.v12i1.949

\begin{tabular}{|c|c|c|}
\hline 9 & Ruang PPG & 9 \\
\hline 10 & Ruang GPM & 36,98 \\
\hline 11 & Ruang Arsip & 36,98 \\
\hline 12 & Ruang Kelas CB2-02 & 36,98 \\
\hline 13 & Ruang Kelas CB2-03 & 36,98 \\
\hline 14 & Ruang Kelas CB2-04 & 36,98 \\
\hline 15 & Ruang Kelas CB2-05 & 36,98 \\
\hline 16 & Toilet & 21,5 \\
\hline 17 & Lorong & 82,74 \\
\hline \multicolumn{2}{|c|}{ Lantai 3 } \\
\hline 18 & Ruang Kelas CB3-06 & 36,98 \\
\hline 19 & Ruang Kelas CB3-07 & 36,98 \\
\hline 20 & Ruang Kelas CB3-08 & 36,98 \\
\hline 21 & Ruang Kelas CB3-09 & 36,98 \\
\hline 22 & Ruang Kelas CB3-10 & 36,98 \\
\hline 23 & Ruang Kelas CB3-11 & 36,98 \\
\hline 24 & Ruang Kelas CB3-12 & 36,98 \\
\hline 25 & Ruang Kelas CB3-13 & 36,98 \\
\hline 26 & Lorong & 82,74 \\
\hline
\end{tabular}

\subsubsection{Data Beban Pencahayaan}

Beban pencahayaan di suatu gedung sangat diperlukan untuk kegiatan di gedung tersebut. Intesitas pencahayaan tergantung seberapa luas ruangan itu. Alat yang digunakan untuk mendapatkan nilai Lux pada tabel 2 menggunakan Lux meter. Kondisi beban pencahayaan di gedung CB FKIP Untirta adalah sebagai berikut:

Tabel 2. Beban Pencahayaan

\begin{tabular}{|c|c|c|c|c|c|}
\hline No & Nama Ruangan & $\begin{array}{c}\text { Standart } \\
\text { Intensitas } \\
\text { Pencahayaan } \\
\text { (lux) }\end{array}$ & $\begin{array}{c}\text { Intensitas } \\
\text { Pencahayaan } \\
\text { Terukur (lux) }\end{array}$ & $\begin{array}{c}\text { Jumlah } \\
\text { Lampu }\end{array}$ & $\begin{array}{c}\text { Daya } \\
\text { Lampu } \\
\text { (Watt) }\end{array}$ \\
\hline 1 & Ruang Dekan & 350 & 71 & 6 & 40 \\
\hline 2 & Ruang Rapat & 300 & 155 & 8 & 40 \\
\hline 3 & Ruang Dekanat & 350 & 147 & 4 & 40 \\
\hline 4 & $\begin{array}{c}\text { Ruang Tata } \\
\text { Usaha }\end{array}$ & 350 & 148 & 12 & 40 \\
\hline 5 & Perpustakaan & 300 & 140 & 16 & 40 \\
\hline 6 & Lorong & 100 & 93 & 14 & 18 \\
\hline 7 & Lab Komputer & 500 & 112 & 16 & 40 \\
\hline 8 & Ruang PPG & 350 & 92 & 3 & 18 \\
\hline 9 & Ruang GPM & 350 & 136 & 8 & 40 \\
\hline 10 & Ruang Perpus 2 & 300 & 126 & 8 & 40 \\
\hline 11 & $\begin{array}{c}\text { Ruang Kelas } \\
\text { CB2-02 }\end{array}$ & 350 & 148 & 8 & 40 \\
\hline
\end{tabular}


Vol. 12, No. 1, Januari - Juni 2020, P-ISSN 1979-0783, E-ISSN 2655-5042

https://doi.org/10.33322/energi.v12i1.949

\begin{tabular}{|c|c|c|c|c|c|}
\hline 12 & $\begin{array}{c}\text { Ruang Kelas } \\
\text { CB2-03 }\end{array}$ & 350 & 147 & 8 & 40 \\
\hline 13 & $\begin{array}{c}\text { Ruang Kelas } \\
\text { CB2-04 }\end{array}$ & 350 & 145 & 8 & 40 \\
\hline 14 & $\begin{array}{c}\text { Ruang Kelas } \\
\text { CB2-05 }\end{array}$ & 350 & 148 & 8 & 40 \\
\hline 15 & Lorong & 100 & 91 & 11 & 18 \\
\hline 16 & $\begin{array}{c}\text { Ruang Kelas } \\
\text { CB3-06 }\end{array}$ & 350 & 155 & 8 & 40 \\
\hline 17 & $\begin{array}{c}\text { Ruang Kelas } \\
\text { CB3-07 }\end{array}$ & 350 & 158 & 8 & 40 \\
\hline 18 & $\begin{array}{c}\text { Ruang Kelas } \\
\text { CB3-08 }\end{array}$ & 350 & 164 & 8 & 40 \\
\hline 19 & $\begin{array}{c}\text { Ruang Kelas } \\
\text { CB3-09 }\end{array}$ & 350 & 161 & 8 & 40 \\
\hline 20 & $\begin{array}{c}\text { Ruang Kelas } \\
\text { CB3-10 }\end{array}$ & 350 & 165 & 8 & 40 \\
\hline 21 & $\begin{array}{c}\text { Ruang Kelas } \\
\text { CB3-11 }\end{array}$ & 350 & 161 & 8 & 40 \\
\hline 22 & $\begin{array}{c}\text { Ruang Kelas } \\
\text { CB3-12 }\end{array}$ & 350 & 164 & 8 & 40 \\
\hline 23 & $\begin{array}{c}\text { Ruang Kelas } \\
\text { CB3-13 }\end{array}$ & 350 & 155 & 8 & 40 \\
\hline 24 & \begin{tabular}{c} 
Lorong \\
\hline
\end{tabular} & 100 & 95 & 14 & 18 \\
\hline
\end{tabular}

\subsubsection{Data Beban Tata Udara/ AC}

Berikut adalah hasil pengukuran dan perhitungan beban tata udara (AC) sesuai dengan standar pengkondisian udara dan observasi dapat dilihat pada tabel 3 .

Tabel 3. Beban Tata Udara

\begin{tabular}{|c|c|c|c|c|c|}
\hline No & $\begin{array}{c}\text { Nama } \\
\text { Ruangan }\end{array}$ & $\begin{array}{c}\text { Waktu } \\
\text { Pemakaian } \\
\text { (Jam/tahun) }\end{array}$ & $\begin{array}{c}\text { Jenis } \\
\text { AC }\end{array}$ & $\begin{array}{c}\text { Daya } \\
\text { AC } \\
\text { (Watt) }\end{array}$ & $\begin{array}{c}\text { Jumlah } \\
\text { AC }\end{array}$ \\
\hline 1 & $\begin{array}{c}\text { Ruang } \\
\text { Dekan }\end{array}$ & 10 & $\begin{array}{c}\text { Splite } \\
\text { 2PK }\end{array}$ & 1660 & 1 \\
\hline 2 & Ruang Rapat & 8 & $\begin{array}{c}\text { Splite } \\
\text { 2PK }\end{array}$ & 1660 & 1 \\
\hline 3 & $\begin{array}{c}\text { Ruang } \\
\text { Dekanat }\end{array}$ & 10 & $\begin{array}{c}\text { Splite } \\
\text { 1PK }\end{array}$ & 800 & 2 \\
\hline 4 & $\begin{array}{c}\text { Ruang Tata } \\
\text { Usaha }\end{array}$ & 10 & $\begin{array}{c}\text { Splite } \\
\text { 2PK }\end{array}$ & 1660 & 3 \\
\hline 5 & $\begin{array}{c}\text { Ruang Tata } \\
\text { Usaha }\end{array}$ & 10 & $\begin{array}{c}\text { Splite } \\
\text { 1PK }\end{array}$ & 800 & 2 \\
\hline 6 & $\begin{array}{c}\text { Perpustakaan } \\
\text { 2PK }\end{array}$ & 1660 & 3 \\
\hline 7 & $\begin{array}{c}\text { Lab } \\
\text { Komputer }\end{array}$ & 10 & $\begin{array}{c}\text { Splite } \\
\text { 2PK }\end{array}$ & 1660 & 2 \\
\hline
\end{tabular}


Energi dan Kelistrikan: Jurnal Ilmiah

Vol. 12, No. 1, Januari - Juni 2020, P-ISSN 1979-0783, E-ISSN 2655-5042 https://doi.org/10.33322/energi.v12i1.949

\begin{tabular}{|c|c|c|c|c|c|}
\hline 8 & Ruang PPG & 10 & $\begin{array}{l}\text { Splite } \\
2 \mathrm{PK}\end{array}$ & 1590 & 1 \\
\hline 9 & Ruang GPM & 10 & $\begin{array}{l}\text { Splite } \\
2 \mathrm{PK}\end{array}$ & 1660 & 1 \\
\hline 10 & $\begin{array}{c}\text { Ruang } \\
\text { Perpus } 2 \\
\end{array}$ & 10 & $\begin{array}{l}\text { Splite } \\
2 \mathrm{PK}\end{array}$ & 1590 & 1 \\
\hline 11 & $\begin{array}{c}\text { Ruang Kelas } \\
\text { CB2-02 }\end{array}$ & 10 & $\begin{array}{l}\text { Splite } \\
2 \mathrm{PK}\end{array}$ & 1660 & 1 \\
\hline 12 & $\begin{array}{c}\text { Ruang Kelas } \\
\text { CB2-03 }\end{array}$ & 10 & $\begin{array}{l}\text { Splite } \\
2 \mathrm{PK}\end{array}$ & 1660 & 1 \\
\hline 13 & $\begin{array}{c}\text { Ruang Kelas } \\
\text { CB2-04 }\end{array}$ & 10 & $\begin{array}{l}\text { Splite } \\
\text { 2PK }\end{array}$ & 1660 & 1 \\
\hline 14 & $\begin{array}{c}\text { Ruang Kelas } \\
\text { CB2-05 }\end{array}$ & 10 & $\begin{array}{l}\text { Splite } \\
\text { 2PK }\end{array}$ & 1660 & 1 \\
\hline 15 & $\begin{array}{c}\text { Ruang Kelas } \\
\text { CB3-06 }\end{array}$ & 10 & $\begin{array}{l}\text { Splite } \\
\text { 2PK }\end{array}$ & 1660 & 1 \\
\hline 16 & $\begin{array}{c}\text { Ruang Kelas } \\
\text { CB3-07 }\end{array}$ & 10 & $\begin{array}{l}\text { Splite } \\
2 \mathrm{PK}\end{array}$ & 1660 & 1 \\
\hline 17 & $\begin{array}{c}\text { Ruang Kelas } \\
\text { CB3-08 }\end{array}$ & 10 & $\begin{array}{l}\text { Splite } \\
2 \mathrm{PK}\end{array}$ & 1660 & 1 \\
\hline 18 & $\begin{array}{c}\text { Ruang Kelas } \\
\text { CB3-09 }\end{array}$ & 10 & $\begin{array}{l}\text { Splite } \\
2 \mathrm{PK}\end{array}$ & 1660 & 1 \\
\hline 19 & $\begin{array}{c}\text { Ruang Kelas } \\
\text { CB3-10 }\end{array}$ & 10 & $\begin{array}{l}\text { Splite } \\
2 \mathrm{PK}\end{array}$ & 1660 & 1 \\
\hline 20 & $\begin{array}{c}\text { Ruang Kelas } \\
\text { CB3-11 }\end{array}$ & 10 & $\begin{array}{l}\text { Splite } \\
2 \mathrm{PK}\end{array}$ & 1660 & 1 \\
\hline 21 & $\begin{array}{c}\text { Ruang Kelas } \\
\text { CB3-12 }\end{array}$ & 10 & $\begin{array}{l}\text { Splite } \\
2 \mathrm{PK}\end{array}$ & 1660 & 1 \\
\hline 22 & $\begin{array}{c}\text { Ruang Kelas } \\
\text { CB3-13 }\end{array}$ & 10 & $\begin{array}{l}\text { Splite } \\
2 \mathrm{PK}\end{array}$ & 1660 & 1 \\
\hline
\end{tabular}

\subsection{Metode Penelitian}

Metode penelitian yang digunakan dalam penelitian ini adalah metode observasi dan konservasi energi. Proses ini meliputi adanya audit energi dan rumus intensitas konsumsi energi (IKE) untuk mendapatkan nilai IKE sebagai faktor utama dalam penilaian gedung yang efisien atau tidak dalam hal penggunaan energinya. Berikut adalah garis besar susunan penelitian ini pada gambar1. 


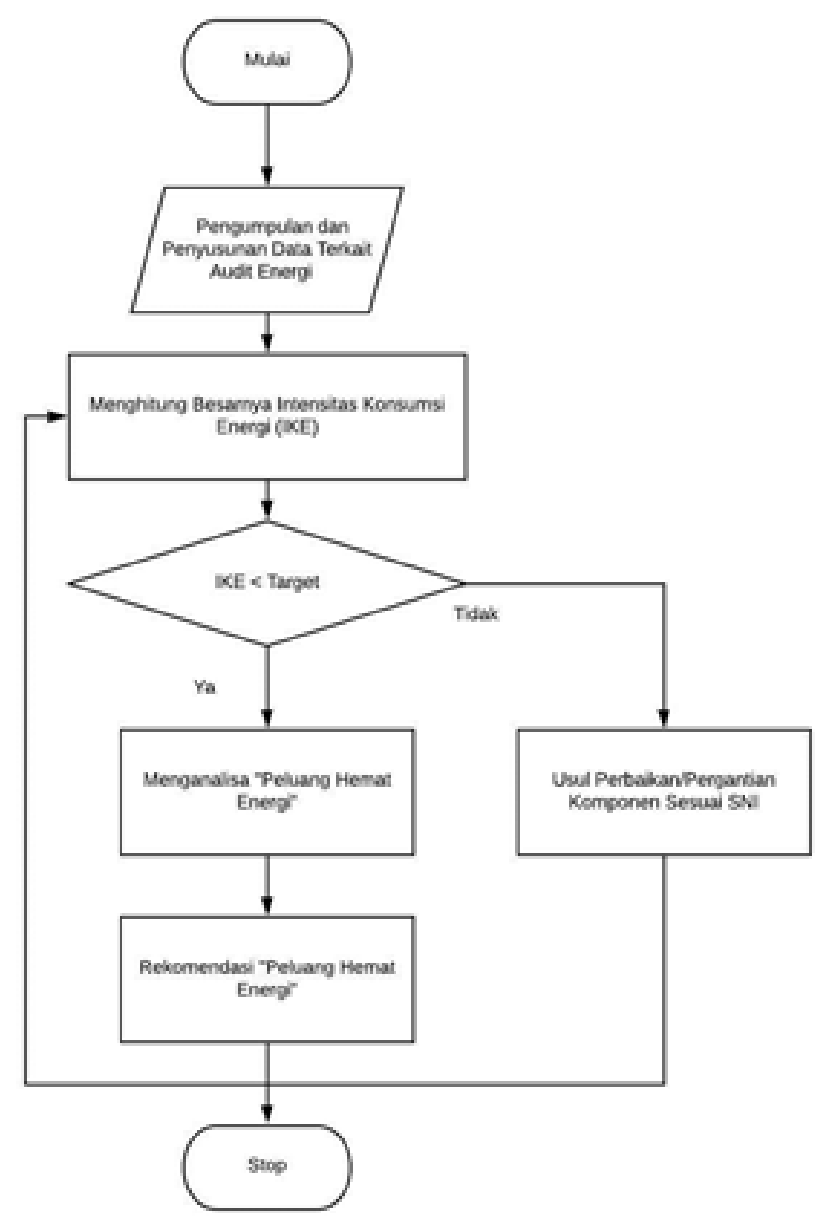

Gambar 1. Flowchart penelitian

Teknik pengumpulan data pada penelitian ini adalah sebagai berikut:
a. Wawancara
Salah satu teknik pengumpulan data yang digunakan untuk menggali data secara lisan.
b. Observasi
Pengamatan sistematis dan pencatatan gejala yang muncul pada objek penelitian. Penelitian ini dilakukan di gedung FKIP Untirta lebih khususnya gedung CB FKIP Untirta.
c. Studi Literatur
Teknik pengumpulan data ini bertujuan untuk mendapatkan informasi yang berasal dari sumber-sumber kepustakaan sebagai landasan pada penelitian.
d. Dokumentasi
Dokumentasi bertujuan untuk memperoleh data secara langsung terkait penelitian.

Berikut ini instrumen yang digunakan pada penelitian ini:
a. Lux Meter
Lux meter adalah alat yang mampu mengetahui dan mengukur seberapa besar intensitas cahaya yang ada di suatu tempat.
b. Hygro Meter
Hygro Meter merupakan sebuah alat yang mampu mengukur kelembaban suatu tempat. 


\section{HASIL DAN PEMBAHASAN}

\subsection{Deskripsi Hasil Penelitian}

Penelitian ini menggunakan sampling 1 gedung 3 lantai yaitu gedung CB yang meliputi ruang kantor dekanat, perpus dan ruang kelas. Pemilihan sampling gedung CB dikarenakan gedung ini tidak hanya digunakan untuk ruang kelas sehingga secara karakteristik penggunaan energi listriknya akan berbeda. Metode penelitian yang digunakan dalam penelitian ini adalah metode observasi dan konservasi energi. Proses ini meliputi adanya audit energi, dimana pada awal proses audit energi adalah dengan persiapan audit energi yaitu pertemuan pendahuluan dan wawancara dengan operator atau pegawai diikuti oleh observasi/survei bangunan sehingga diperoleh dokumentasi yang mendukung terkait penelitian ini untuk melihat atau mengetahui nilai intensitas konsumsi energi dan peluang penghematan energi potensial.

\subsection{Hasil Penelitian}

3.2.1. Hasil Analisis Perhitungan Beban Pencahayaan

Pengukuran beban pencahayaan ini menggunakan luxmeter dan untuk mengukur luasnya menggunakan meteran luas serta dicocokkan dengan groundmap gedung yang sudah dirancang sebelumnya. Mayoritas ruangan menggunakan lampu TL 40W dan selebihnya menggunakan lampu LED 18W. Ini merupakan tabel dan grafik penggunaan beban pencahayaan selama setahun atau per tahun tiap ruangan di gedung CB FKIP Untirta sebagai berikut:

Tabel 4. Perhitungan Beban Pencahayaan

\begin{tabular}{|c|c|c|c|c|c|c|c|}
\hline \multirow{2}{*}{ No } & \multirow{2}{*}{$\begin{array}{c}\text { Nama } \\
\text { Ruangan }\end{array}$} & \multirow{2}{*}{$\begin{array}{c}\text { Jumlah } \\
\text { lampu }\end{array}$} & \multicolumn{2}{|c|}{\begin{tabular}{c} 
Luas Area \\
lampu \\
\cline { 4 - 5 }
\end{tabular}} & $\begin{array}{c}\text { Daya } \\
\text { (W) }\end{array}$ & Waktu & $\begin{array}{c}\text { Konsumsi } \\
\text { daya } \\
(\mathrm{kWh})\end{array}$ \\
\hline 1 & Ruang Dekan & 6 & 4,3 & 8,6 & 40 & 2200 & 528 \\
\hline 2 & Ruang Rapat & 8 & 4,3 & 8,6 & 40 & 1600 & 512 \\
\hline 3 & $\begin{array}{c}\text { Ruang } \\
\text { Dekanat }\end{array}$ & 4 & 8,6 & 8,6 & 40 & 2200 & 352 \\
\hline 4 & $\begin{array}{c}\text { Ruang Tata } \\
\text { Usaha }\end{array}$ & 12 & 8,6 & 8,6 & 40 & 2200 & 1056 \\
\hline 5 & Perpustakaan & 16 & 8,6 & 8,6 & 40 & 2000 & 1280 \\
\hline 6 & Lorong & 14 & 39,4 & 2,1 & 18 & 4380 & 1103,76 \\
\hline 7 & $\begin{array}{c}\text { Lab } \\
\text { Komputer }\end{array}$ & 16 & 8,6 & 8,6 & 40 & 1950 & 1248 \\
\hline 8 & Ruang PPG & 3 & 4,3 & 2,1 & 18 & 2000 & 108 \\
\hline 9 & Ruang GPM & 8 & 4,3 & 8,6 & 40 & 2000 & 640 \\
\hline 10 & Ruang Arsip & 8 & 4,3 & 8,6 & 40 & 2000 & 640 \\
\hline 11 & Ruang Kelas & 8 & 4,3 & 8,6 & 40 & 1950 & 624 \\
\hline 12 & Lorong & 11 & 39,4 & 2,1 & 18 & 4380 & 867,24 \\
\hline 24 & Lorong & 14 & 39,4 & 2,1 & 18 & 4380 & 1103,76 \\
\hline
\end{tabular}




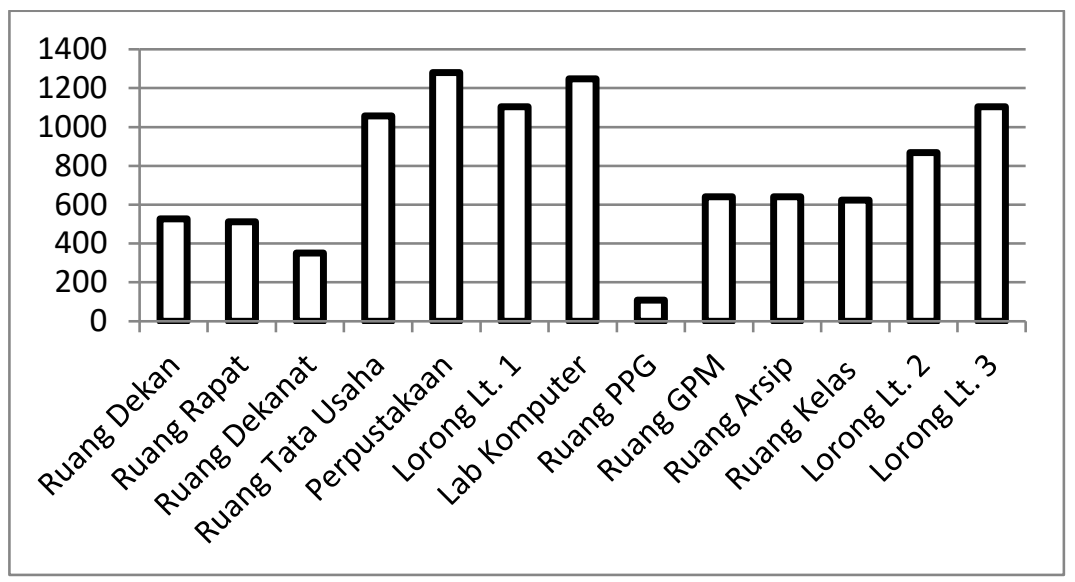

Gambar 2. Grafik Beban Pencahayaan

Sesuai grafik dan tabel konsumsi daya beban pencahayaann paling tinggi yaitu di ruangan perpustakaan dan yang paling rendah adalah ruang PPG. Total konsumsi beban pencahayaan adalah $16574,76 \mathrm{kWh} /$ tahun.

\subsubsection{Hasil Analisis Perhitungan Beban Tata Udara}

Pengukuran beban tata udara menggunakan data sheet yang terdapat di AC/pendingin tersebut. Berikut adalah tabel konsumsi beban tata udara pertahun sebagai berikut:

Tabel 5. Perhitungan Beban Tata Udara

\begin{tabular}{|c|c|c|c|c|c|c|}
\hline No & $\begin{array}{c}\text { Nama } \\
\text { Ruangan }\end{array}$ & $\begin{array}{c}\text { Waktu } \\
\text { Pemakaian } \\
\text { (Jam/tahun) }\end{array}$ & $\begin{array}{c}\text { Jenis } \\
\text { AC }\end{array}$ & $\begin{array}{c}\text { Daya } \\
\text { AC } \\
\text { (Watt) }\end{array}$ & Jumlah AC & $\begin{array}{c}\text { Konsumsi } \\
\text { daya } \\
\text { pertahun } \\
\text { (kWh) }\end{array}$ \\
\hline 1 & Ruang Dekan & 2200 & $\begin{array}{c}\text { Splite } \\
\text { 2PK }\end{array}$ & 1660 & 1 & 3652 \\
\hline 3 & Ruang Rapat & 1600 & $\begin{array}{c}\text { Splite } \\
\text { 2PK }\end{array}$ & 1660 & 1 & 2656 \\
\hline 4 & $\begin{array}{c}\text { Ruang } \\
\text { Dekanat }\end{array}$ & 2200 & $\begin{array}{c}\text { Splite } \\
\text { 1PK }\end{array}$ & 800 & 2 & 3520 \\
\hline 5 & Perpustakaan & 2000 & $\begin{array}{c}\text { Splite } \\
\text { 2PK }\end{array}$ & 1660 & 3 & 9960 \\
\cline { 3 - 7 } & 2200 & $\begin{array}{c}\text { Splite } \\
\text { 2PK }\end{array}$ & 1660 & 3 & 10956 \\
\hline 7 & $\begin{array}{c}\text { Lab } \\
\text { Komputer }\end{array}$ & 1950 & $\begin{array}{c}\text { Splite } \\
\text { RuK }\end{array}$ & 1660 & 2 & 6474 \\
\hline 8 & Ruang GPM & 2000 & $\begin{array}{c}\text { Splite } \\
\text { 2PK }\end{array}$ & 1660 & 1 & 3320 \\
\hline 9 & Ruang Arsip & 2000 & $\begin{array}{c}\text { Splite } \\
\text { 2PK }\end{array}$ & 1590 & 1 & 3180 \\
\hline 10 & Ruang Kelas & 1950 & $\begin{array}{c}\text { Splite } \\
\text { 2PK }\end{array}$ & 1660 & 1 & 3237 \\
\hline
\end{tabular}




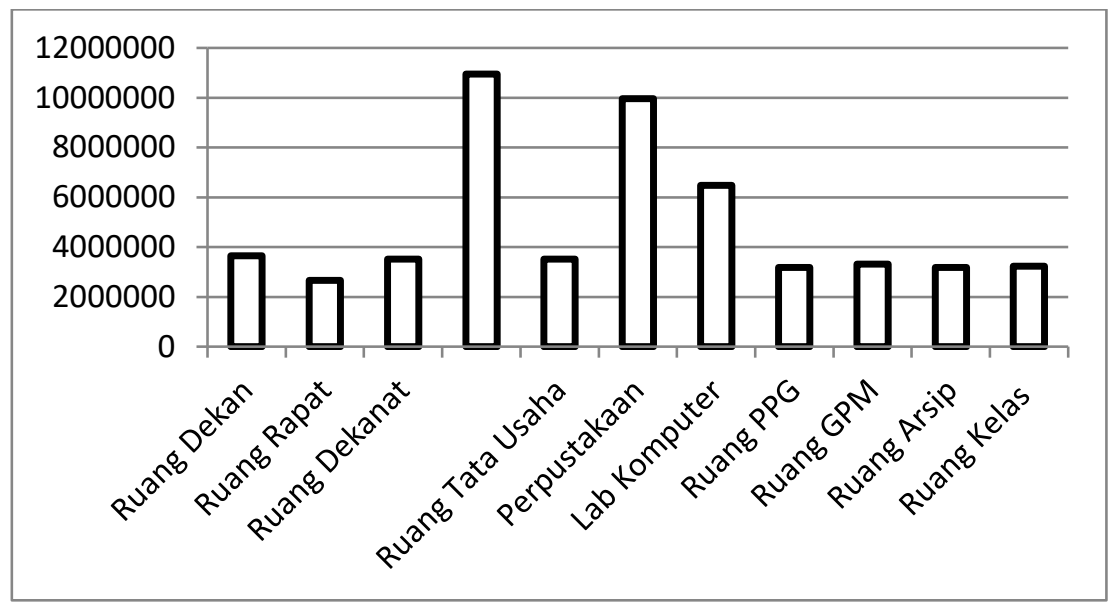

Gambar 3. Grafik Beban Tata Udara

Sesuai grafik dan tabel konsumsi daya beban tata udara atau AC paling tinggi yaitu di ruangan tata usaha dan yang paling rendah adalah ruang rapat. Total konsumsi beban tata udara adalah 89262 $\mathrm{kWh} / \mathrm{tahun}$.

\subsubsection{Analisis Perhitungan Intensitas Konsumsi Energi (IKE)}

Berdasarkan perhitungan diperoleh hasil bahwa konsumsi energi listrik di gedung CB sebesar $121903 \mathrm{kWh} /$ tahun. Dengan hasil tersebut, untuk mendapatkan nilai IKEnya adalah sebagai berikut:

Rumus IKE:

$$
\begin{aligned}
& I K E=\frac{k W h \text { Total }}{\text { Luas Bangunan }} \\
& I K E=\frac{121903}{479}=254,5 \mathrm{kWh} / \mathrm{m}^{2}
\end{aligned}
$$

Dengan diperoleh hasil tersebut, bisa diketahui bahwa nilai IKE di gedung CB FKIP Untirta masih tidak efisien. Ini didasarkan pada parameter ASEAN-USAID yang berkisar di $240 \mathrm{kWh} / \mathrm{m}^{2}$. Pada parameter nilai IKE yaitu bila melewati parameter tersebut maka, gedung tersebut tidak efisien dalam hal penggunaan energi listriknya.

\subsubsection{Peluang Penghematan Energi}

Berdasarkan hasil dari nilai IKE di gedung CB FKIP Untirta maka, dibutuhkan solusi untuk penghematan energi. Oleh sebab itu, terdapat beberapa macam yang yang menjadi fokus dalam hal penghematan energi:

a. Beban pencahayaan

Mengganti lampu dengan jenis lampu LED. Sebagai perbandingan lampu tl $40 \mathrm{~W}$ dengan $\cos \varphi=0,93$ adalah sebagai berikut:

$$
S=\frac{40}{0,93}=43,01 \mathrm{~W}
$$

Lalu, lampu Led 40W dengan $\cos \varphi=0,95$ adalah sebagai berikut:

$$
S=\frac{40}{0,95}=42,10 \mathrm{~W}
$$

Perhitungan perbandingan lampu tl dan led yang sama-sama 40W. didapatkan hasil bahwa lampu Led lebih hemat daripada lampu TL. Namun, lebih baik dalam penghematan energi 


\section{Energi dan Kelistrikan: Jurnal Ilmiah}

Vol. 12, No. 1, Januari - Juni 2020, P-ISSN 1979-0783, E-ISSN 2655-5042

https://doi.org/10.33322/energi.v12i1.949

daya yang ingin digunakan lebih kecil daripada daya lampu sekarang, misalnya menggunakan lampu Led 20W.

b. Beban Tata Udara

Bahwa refrigeran R32 masih tergolong kurang baik dalam hal konsumsi energi. Oleh sebab itu, refrigeran yang lebih hemat energi yaitu refrigeran campuran R32 dan R290 dengan perbandingan $70 \%: 30 \%$ berdasarkan berat.

c. Durasi Penggunaan

Pengurangan pemakaian konsumsi energi misalnya pada beban AC dari 10 jam menjadi 8 jam perhari atau selama perbulan 160 jam dapat mengurangi beban pemakaian sebelumnya sebesar $20 \%$.

$$
\text { Efisiensi }=\frac{5260-4208 \times 100 \%}{5260}=20 \%
$$

\section{KESIMPULAN DAN SARAN}

Berdasarkan hasil dan pembahasan maka diperoleh kesimpulan bahwa Nilai IKE gedung CB FKIP Untirta sebesar 254,5. Dengan diperoleh hasil tersebut, bisa diketahui bahwa nilai IKE di gedung CB FKIP Untirta masih tidak efisien. Ini didasarkan pada parameter ASEAN-USAID yang berkisar di 240. Performa konsumsi energi di gedung CB FKIP Untirta yaitu mulai dari beban pencahayaan sebesar 16574,76 kWh/tahun, beban tata udara atau AC sebesar $89262 \mathrm{kWh} /$ tahun, dan beban daya lainnya sebesar $16028,5 \mathrm{kWh} /$ tahun. Sehingga, solusi penghematan energi yaitu mengganti lampu TL 40W dengan lampu Led atau dengan mengganti lampu TL yang lebih kecil wattnya dan dari segi beban tata udara atau AC yaitu mengganti refrigeran R32 dengan refrigeran campuran R32 dan R290 yang terbukti cukup hemat dalam hal penghematan dan efisiensi energi. Serta, durasi menggunakan energi listriknya yang harus dihemat lagi.

Berdasarkan hasil penelitian yang telah dilaksanakan, saran dalam pengembangan penelitian selanjutnya adalah penelitian audit energi secara detail atau lanjut agar lebih presisi.

\section{DAFTAR PUSTAKA}

Kutipan berturut-turut dalam tanda kurung [1]. Kalimat tanda baca berikut braket [2]. Merujuk hanya untuk nomor referensi, seperti pada [3] -Jangan menggunakan "Ref. [3] "atau" referensi [3]. Minimal daftar pustaka sebanyak 5 Kutipan.

[1] Hamdani, Hamdani, Muhammad Thahir, and Nurhayati Nurhayati, (2016) "AUDIT ENERGI SISTEM KELISTRIKAN GEDUNG POLITEKNIK NEGERI UJUNG PANDANG MENGGUNAKAN SCADA SEBAGAI INSTRUMEN PENGUKURAN PERMANEN." Jurnal Teknologi Elekterika 13, no. 2 : 213-224.

[2] ICED Project, (2014) "Panduan Penghematan Energi Di Gedung Pemerintah: Sesuai Amanat Peraturan Menteri ESDM No.13 Tahun 2012 Tentang Penghematan Pemakaian Listrik”. Jakarta: USAID-ICED.

[3] Indonesia, Standar Nasional, (2000) "Prosedur Audit Energi Pada Bagunan Gedug. Badan Standardisasi Nasional, 2000.

[4] Indonesia, Standar Nasional, (2011) “Prosedur Audit Energi Pada Bagunan Gedun”. Badan Standardisasi Nasional. 
[5] Koes Indrakoesoema, K. I., and Yayan Andriyanto, (2005). "KAJIAN FAKTOR DAYA (COS j) LAMPU TL PADA PENERANGAN DI RSG-GAS.” In PROSIDING SEMINAR HASIL PENELITIAN PTRR. PRSG-BATAN.

[5] Molina-Solana, Miguel, María Ros, M. Dolores Ruiz, Juan Gómez-Romero, and María J. Martín-Bautista, (2017) "Data Science for Building Energy Management: A Review." Renewable and Sustainable Energy Reviews 70 : 598-609.

[6] Temaja, I. Wayan, Made Ery Arsana, and Luh Putu Ike Midiani, (2018) "KAJIAN EKSPERIMENTAL CAMPURAN R-32/R-290 PENGGANTI REFRIGERAN R-32 PADA AC SPLIT DOMESTIK." Matrix: Jurnal Manajemen Teknologi Dan Informatika 8, no. 3 : 74-78. 